Atmos. Chem. Phys., 10, 9283-9293, 2010

www.atmos-chem-phys.net/10/9283/2010/

doi:10.5194/acp-10-9283-2010

(C) Author(s) 2010. CC Attribution 3.0 License.

\title{
Chemistry of rain events in West Africa: evidence of dust and biogenic influence in convective systems
}

\author{
K. Desboeufs ${ }^{1}$, E. Journet ${ }^{1}$, J.-L. Rajot $^{2}$, S. Chevaillier ${ }^{1}$, S. Triquet ${ }^{1}$, P. Formenti ${ }^{1}$, and A. Zakou ${ }^{2}$ \\ ${ }^{1}$ LISA, UMR CNRS 7583, Université Paris Est Créteil et Université Paris Diderot, Institut Pierre Simon Laplace, \\ Créteil, France \\ ${ }^{2}$ IRD - UMR 211 Bioemco, Niamey, Niger
}

Received: 14 February 2010 - Published in Atmos. Chem. Phys. Discuss.: 21 June 2010

Revised: 10 September 2010 - Accepted: 23 September 2010 - Published: 1 October 2010

\begin{abstract}
This paper documents the chemical composition of 7 rain events associated with mesoscale convective systems sampled at the supersite of Banizoumbou, Niger, during the first special observation periods (June-July 2006) of the African Monsoon Multidisciplinary Analyses (AMMA) experiment. Time-resolved rain sampling was performed in order to discriminate the local dust scavenged at the beginning of rain event from the aerosol particles incorporated in the cloud at the end of the rain. The total elemental composition is dominated by $\mathrm{Al}, \mathrm{Si}, \mathrm{Fe}$ and $\mathrm{Ca}$, indicating a high influence of dust and limited marine or anthropogenic contribution. After the aerosol wash-out, the elemental concentrations normalized to $\mathrm{Al}$ and the microscopic observations of diatoms, a tracer of the Bodélé depression, both indicate that the total elemental composition of rainwater is controlled by dust originating from North-eastern Saharan sources and probably incorporated in the convective cloud from the Harmattan layer. The low variability of the rain composition over the measurement period indicates a regional and temporal homogeneity of dust composition in the Harmattan layer. In the dissolved phase, the dominant anions are nitrate $\left(\mathrm{NO}_{3}^{-}\right)$, sulphate $\left(\mathrm{SO}_{4}^{2-}\right)$ and chloride $\left(\mathrm{Cl}^{-}\right)$. However, between June and July we observe an increasing contribution of the organic anions (formate, acetate, oxalate) associated with biogenic emissions to the total ion composition. These results confirm the large influence of biogenic emissions on the rain composition over Sahel during the wet season. The paper concludes on the capacity of mesoscale convective systems to carry si-
\end{abstract}

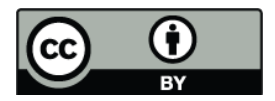

Correspondence to: K. Desboeufs (desboeufs@lisa.univ-paris12.fr) multaneously dust and biogenic compounds originating from different locations and depose them jointly. It also discusses the potential biogeochemical impact of such a phenomenon.

\section{Introduction}

West African monsoon is characterised by a convective activity resulting from the abrupt change in atmospheric circulation occurring over this region between June and July. The propagating mesoscale convective systems (MCS) associated with the summer monsoon produce about $80 \%$ of the total rainfall in the area, notably on the northern edge of the West African Intertropical Convergence Zone (ITCZ) in Sahel (Mohr, 2004). They are therefore an important feature of the West African rain climatology and hence of the hydrological cycle (Lebel et al., 1997). Moreover, the MCS are responsible for the major part of the annual local wind erosion and hence for most of the Sahelian dust emission (Rajot and Valentin, 2001). The West African monsoon associated with a severe drought for the past 30 years in the Sahelian belt had significant consequences for the environment and for key resources as water, land-productivity, and human health (Redelsperger et al., 2006). In consequence, for predicting the impacts of the West African monsoon in a general context of climate change, the assessment of the processes involved in the development and the fate of the MCS, and notably of the precipitating clouds, is critical. In particular, because cloud formation strongly depends on the presence of condensation nuclei $(\mathrm{CCN})$, the aerosol-water cycle interaction must be better understood. However, in the case of MCS developing in the monsoon regions, the nature of the $\mathrm{CCN}$

Published by Copernicus Publications on behalf of the European Geosciences Union. 
remains unclear. Indeed, $\mathrm{CCN}$ activity in West Africa is part of a complex system involving at the same time cloud microphysics and aerosol chemistry. During the monsoon season, the southwesterly winds transporting marine and biogenic air masses and the dust-laden north-easterly dry winds, called Harmattan, converge over the Sahel (Janicot et al., 2008). Submicron dust particles, composed primarily of insoluble minerals, are typically assumed to be inefficient $\mathrm{CCN}$ until they have become mixed with hygroscopic material (e.g., sulphates, nitrates, Liu et al., 2005). However, recent laboratory work show an appreciable CCN activity of "fresh" dust at relative humidity $<90 \%$ (Koehler et al., 2009).

The chemical composition of wet precipitation is mainly determined by three mechanisms: condensation of water vapor on cloud condensation nuclei, capture of species inside the cloud droplets (rain-out) and scavenging process below cloud (wash-out). The subdivision of a single rain event into consecutive fractions, by means of a high resolution sampling, allows 1) the study of the local atmospheric washout processes and 2) to follow the variability of rain chemical composition with time. This also provides an image of the cloud formation history. With this idea of studying the behavior of dust in precipitating convective systems in mind, we followed the evolution of the chemical composition of rainwater in the Sahelian MCS by rain sequential sampling. We have discriminated the different stages of rainfall in terms of their measured components, i.e., major dissolved organic and inorganic ions and several major, minor, and trace elements, as well as their partition between dissolved and particulate phases. Sampling was performed in Niger during the Monsoon Onset- and the Peak MonsoonSpecial Observing Periods (SOPs) field campaigns \#1\&2 of the AMMA program (June-July 2006, Redelsperger and al., 2006). This time of year is the pronest to high dust activity and is the period when most of the intense dust outbreaks are observed over the North Atlantic (Engelstaedter and Washington, 2007). Over the Sahel, the propagating MCS and their associated density currents offer the most efficient mechanism for the lifting of dust and its injection to altitudes favorable for long-range transport, particularly at the beginning of the monsoon season (e.g. Sterk, 2003). The measurements were operated at the remote sampling site of Banizoumbou (Niger) in the core of the Sahel and on the pathway of numerous propagating MCS.

This paper reports on the observations of the sequential time-resolved precipitating convective events of AMMA SOP1\&2. Data will be discussed with the double aim of identifying the aerosols incorporated in the precipitating cloud, and of studying the interactions between Sahelian atmosphere and convective clouds.

\section{Method}

Ground-based measurements were performed at the instrumented station of Banizoumbou $\left(13^{\circ} 31 \mathrm{~N}, 2^{\circ} 37 \mathrm{E}\right)$, a remote site located about $60 \mathrm{~km}$ east of Niamey (Niger) (Rajot et al., 2008). The operational period was from 1 June to 17 July 2006, thus encompassing the pre- and post- Monsoon's onset SOPs field phases. This operational period corresponds to the SOP 1\&2 AMMA intensive phases as defined by the international AMMA implementation plan (Lebel et al., 2010).

\subsection{Sampling}

The time-resolved rain sampling was performed in order to partition the scavenged local dust at the beginning of rain event and the aerosol particles incorporated in the cloud at the end of the rain. To do so, an automatic sequential raingauge was used to collect individual rain events. This sampler can collect rainwater on an event basis or as sequential segments within an individual rain event. The heart of this instrument is a 6-place bottle-holder carousel that rotates and exposes successive rainwater samplers under a $50 \mathrm{~cm}^{2}$ funnel. The sampling frequency is controlled by the rotation of the carousel and conducted by the operator from a distance in function of the intensity of precipitation. This procedure ensures collection of a volume (in average $100 \mathrm{~mL}$ ) adequate for the subsequent analyses and explains that sampling was performed at unequal time intervals. The last samplers stayed installed until the end of the rain event. Samples were collected consequently without interruption. The open and close positions of the rain-gauge are triggered by the rain sensor. Immediately after the end of the rain event, the bottles were recuperated and the samples filtered on pre-cleaned $0.2-\mu \mathrm{m}$ pore size polycarbonate Nuclepore ${ }^{\circledR}$ filters. The rainwater filtration and the preparation of the samples were all conducted in a laminar-flow clean bench. A part of the samples was used in-situ to measure $\mathrm{pH}$ and the rest was conditioned for subsequent analysis in the laboratory (in Paris). A raingauge was also used to determine the total content and intensity of the rainfall. Due to the "mud" effect of the first rain droplets (see Sect. 3.1.), it is not always easy to locate the exact beginning of the rain event. The comparison of the rain-gauge measurements with the volumes of the collected rains shows that on average $87 \%$ of the events was collected.

Besides rain sampling, (1) aerosol mass concentration (by Tapered Oscillating Microbalance (TEOM)); (2) particle number distribution between 0.3 and $20 \mu \mathrm{m}$ diameter (by Grimm optical particle counter 1.108); and (3) filter sampling for the determination of the aerosol chemical composition were measured between the rain events (Rajot et al., 2008). Meteorological sensors were also used to determine temperature, humidity, wind speed and direction. Finally, the local wind erosion periods were determined with a saltiphone monitoring the movements of eroded sand grains in 
the saltation layer, just above the soil surface (Spaan and van den Abeele, 1991).

\subsection{Analysis}

Immediately after the rain event, the $\mathrm{pH}$ was measured in the non-filtered fraction of the rainwater using an Orion $\mathrm{pH}$ meter and combination electrode. Dissolved metals were determined on stored, filtered and acidified samples. These $60 \mathrm{ml}$ samples were acidified to $\mathrm{pH} 1$ with Suprapur ${ }^{\circledR} \mathrm{HNO}_{3}$ in polypropylene bottles and stored in the dark at $4{ }^{\circ} \mathrm{C}$ until analyzed by ICP-AES (Perkin Elmer Optima 3000XL) according to Desboeufs et al. (2003) for dissolved ions (Na, $\mathrm{Ca}, \mathrm{Fe}, \mathrm{Al}, \mathrm{Si}, \mathrm{K}, \mathrm{Mg}$ and $\mathrm{P}$ ). Upon collection, a part of the filtered samples was frozen. Back in the laboratory in Paris, they were melted to measure the major inorganic and organic anions species $\left(\mathrm{Cl}^{-}, \mathrm{Br}^{-}, \mathrm{NO}_{2}^{-}, \mathrm{NO}_{3}^{-}, \mathrm{SO}_{3}^{2-}, \mathrm{SO}_{4}^{2-}\right.$, acetate, formate, propionate, butyrate, $\mathrm{MSA}^{-}$, pyruvate, valerate, and oxalate) and cations $\left(\mathrm{NH}_{4}^{+}\right)$using ionic chromatography (Dionex 4500i device), equipped with an AS11-HC column associated with an AG11 pre-column. The analyses were carried out less than one month after collection. Control samples (synthetic rainwater spiked with known concentrations of inorganic and organic anions) showed that there was no problem of anion conservation with these conditions of storage. For simultaneous separation of inorganic and shortchain organic anions, gradient elution by $1-66 \mathrm{mM} \mathrm{NaOH}$ $(1.5 \mathrm{~mL} / \mathrm{min})$ was employed. Blanks were treated in the same way for quality assurance purposes. Further, the ion balance was computed by summing up the equivalent concentrations of cations i+ and anions i- of the samples. The sum of anion equivalent concentrations should be equal to that of the cations according to the condition of electric neutrality.

Insoluble particulate elemental concentrations for all the rain filters were obtained by wavelength dispersive X-ray fluorescence (WD-XRF) using a PW-2404 spectrometer by Panalytical. Excitation X-rays are produced by a Coolidge tube $(\operatorname{Imax}=125 \mathrm{~mA}, \mathrm{~V} \max =60 \mathrm{kV})$ with a $\mathrm{Rh}$ anode; primary X-ray spectrum can be controlled by inserting filters (Al, at different thickness) between the anode and the sample. Each element was analyzed three times, with specific conditions (voltage, tube filter, collimator, analyzing crystal and detector), lasting 8 to $10 \mathrm{~s}$. Data were collected for nine elements ( $\mathrm{Na}, \mathrm{Mg}, \mathrm{Al}, \mathrm{Si}, \mathrm{P}, \mathrm{K}, \mathrm{Ca}, \mathrm{Ti}, \mathrm{Fe})$ using SuperQ software.

Total elemental concentration has been obtained by summing dissolved and particulate fractions. The percent by mass of each individual measured element to the total elemental mass was then calculated.

\section{Results}

\subsection{General conditions}

Several studies have illustrated that the rain events in Niger, and notably around Niamey, are mainly related to two kinds of convective systems (e.g. Mathon et al., 2002):

- Squall lines mesoscale convective systems (SLMCS), which are propagating systems formed in the elevated terrains East of Niamey (Jos Plateau or Aïr), generally move towards the west or -southwest, and dominate rainfall production in this region.

- Isolated convective cells (Nonsquall-MCS), which are formed -and decay- locally.

Between the 1 June and the 17 July, 7 rain events have been collected, 4 of which were of the SLMCS type. Table 1 details the sampling characteristics of these rain events. We distinguished their convective origins using Satellite and Radar observations (MeteosatIR10.8 with tropical color threshold and Rapid Developing Thunderstorm product, and MIT radar) obtained from the operational database of the AMMA SOP (Fig. 1). These observations show that the origin of SLMCS is always located in the Eastern or North-eastern areas of Banizoumbou. The local convective events dominate the beginning of the sampling period, whereas the SLMCS prevail in July. The analysis of the convective activity in Africa during AMMA campaign (Janicot et al., 2008) has shown that the transition phase that corresponds to the monsoon onset was centred on 3 July in 2006, which is ten days later than the mean onset date (1968-2005). The monsoon onset is followed by the installation of the monsoon and the deep convection over the Sahelian latitudes with the centre of gravity of the ITCZ located between $10^{\circ} \mathrm{N}$ and $12^{\circ} \mathrm{N}$ during the whole summer. Our samples reflect these conclusions on the delay of monsoon onset, since the precipitating events in July, when the monsoon is installed, present higher rainfall depth compared to the ones of June (Table 1).

For all the collected events, a first dust outbreak in association with strong surface winds gets ahead of rain associated with lower wind velocity (Fig. 2). The increase of wind speed with the passage of MCS on the site is usually associated with a change of wind direction from Southwest to North-east as displayed in Fig. 2. These results are consistent with the general circulation expected for West Africa at this time of the year (Janicot et al., 2008). Indeed, in June and July, the ITD (Inter-Tropical Discontinuity), which is the confluence of the south-westerly monsoon winds with the north-easterly dry Harmattan winds, is positioned between $15^{\circ} \mathrm{N}$ and $20^{\circ} \mathrm{N}$. Thus, the surface monsoon winds extending in Niger up to $15^{\circ} \mathrm{N}-20^{\circ} \mathrm{N}$ are overlain by Harmattan winds, transporting dust above $2000 \mathrm{~m}$ in the Saharan Air Layer (SAL) (Bou Karam et al., 2008; Lothon et al., 2008). During the MCS, the surface winds are dominated 
Table 1. Sample Identification and Main Operational Details for the rainwater sampled during AMMA SOP 1 and 2. Grey lines correspond to rain events collected from SLMCS. Samples presented in italic correspond with the samples which the elemental total composition is directly affected by local wash-out.

\begin{tabular}{|c|c|c|c|c|c|c|c|}
\hline $\begin{array}{l}\text { Sample } \\
\text { ID }\end{array}$ & & Date & $\begin{array}{r}\text { Beginning of } \\
\text { sampling (UTC) }\end{array}$ & $\begin{array}{l}\text { duration } \\
\text { (hh:mm) }\end{array}$ & $\begin{array}{r}\text { Particulate mass } \\
\text { concentration } \\
(\mathrm{mg} / \mathrm{L})\end{array}$ & $\begin{array}{r}\text { Depth } \\
\text { rainfall }(\mathrm{mm})\end{array}$ & $\begin{array}{l}\text { SLMCS } \\
\text { developing zone }\end{array}$ \\
\hline \multirow[t]{4}{*}{ Rain no. 1} & $R 1 B 1$ & $04 / 06 / 2006$ & $16: 35$ & $00: 05$ & 268 & \multirow[t]{4}{*}{4.5} & \\
\hline & $R 1 B 2$ & $04 / 06 / 2006$ & $16: 40$ & $00: 04$ & 80 & & \\
\hline & R1B3 & $04 / 06 / 2006$ & $16: 45$ & 00:04 & 74 & & \\
\hline & R1B4 & $04 / 06 / 2006$ & $16: 50$ & 00:09 & 44 & & \\
\hline \multirow[t]{2}{*}{ Rain no. 2} & $R 2 B 1$ & 08/06/2006 & $18: 31$ & $00: 13$ & 3127 & \multirow[t]{2}{*}{1.8} & \\
\hline & $R 2 B 2$ & 08/06/2006 & $18: 44$ & $00: 05$ & 161 & & \\
\hline \multirow[t]{4}{*}{ Rain no. 3} & $R 3 B 1$ & $17 / 06 / 2006$ & $22: 10$ & $00: 56$ & 3071 & \multirow[t]{4}{*}{6.2} & \multirow{4}{*}{$\begin{array}{l}\text { Central Niger (North of } \\
\text { Sahel and border of Aïr) }\end{array}$} \\
\hline & $R 3 B 2$ & $17 / 06 / 2006$ & $23: 06$ & $01: 27$ & 176 & & \\
\hline & R3B3 & $18 / 06 / 2006$ & $00: 33$ & $00: 41$ & 55 & & \\
\hline & R3B4 & $18 / 06 / 2006$ & $01: 15$ & $00: 34$ & 27 & & \\
\hline \multirow[t]{6}{*}{ Rain no. 4} & $R 4 B 1$ & $01 / 07 / 2006$ & $23: 12$ & $00: 05$ & 98 & \multirow[t]{6}{*}{17} & \multirow{6}{*}{$\begin{array}{l}\text { Central Niger (North of } \\
\text { Sahel and border of Aïr) }\end{array}$} \\
\hline & $R 4 B 2$ & $01 / 07 / 2006$ & $23: 17$ & $00: 06$ & 30 & & \\
\hline & $R 4 B 3$ & $01 / 07 / 2006$ & $23: 25$ & $00: 22$ & 81 & & \\
\hline & R4B4 & 01/07/2006 & $23: 47$ & $00: 25$ & 6 & & \\
\hline & R4B5 & $02 / 07 / 2006$ & $00: 11$ & 01:18 & 14 & & \\
\hline & R4B6 & $02 / 07 / 2006$ & 01:31 & 03:29 & 24 & & \\
\hline \multirow[t]{5}{*}{ Rain no. 5} & $R 5 B 1$ & $11 / 07 / 2006$ & $17: 37$ & 00:08 & 172 & \multirow[t]{5}{*}{19} & \\
\hline & $R 5 B 2$ & $11 / 07 / 2006$ & $17: 45$ & 00:07 & 48 & & \\
\hline & R5B3 & $11 / 07 / 2006$ & $17: 52$ & 00:09 & 17 & & \\
\hline & R5B4 & $11 / 07 / 2006$ & 18:02 & $00: 14$ & 17 & & \\
\hline & R5B5 & $11 / 07 / 2006$ & $18: 17$ & 00:59 & 13 & & \\
\hline \multirow[t]{6}{*}{ Rain no. 6} & $R 6 B 1$ & $14 / 07 / 2006$ & $04: 28$ & $00: 12$ & 51 & \multirow[t]{6}{*}{20.6} & \multirow{6}{*}{$\begin{array}{l}\text { Central Niger (North of } \\
\text { Sahel and border of Aïr) }\end{array}$} \\
\hline & $R 6 B 2$ & $14 / 07 / 2006$ & $04: 40$ & $00: 11$ & 11 & & \\
\hline & R6B3 & $14 / 07 / 2006$ & $04: 53$ & $00: 37$ & 8 & & \\
\hline & R6B4 & $14 / 07 / 2006$ & $05: 31$ & $00: 38$ & 15 & & \\
\hline & R6B5 & $14 / 07 / 2006$ & $06: 10$ & $00: 42$ & 11 & & \\
\hline & R6B6 & $14 / 07 / 2006$ & $06: 53$ & 01:09 & 4 & & \\
\hline \multirow[t]{6}{*}{ Rain no. 7} & $R 7 B 1$ & $17 / 07 / 2006$ & $06: 24$ & $00: 05$ & 81 & \multirow[t]{6}{*}{35.2} & \multirow{6}{*}{$\begin{array}{l}\text { South Eastern of Niger } \\
\text { (border of Nigeria) }\end{array}$} \\
\hline & $R 7 B 2$ & $17 / 07 / 2006$ & $06: 30$ & 00:09 & 53 & & \\
\hline & R7B3 & $17 / 07 / 2006$ & $06: 40$ & $00: 12$ & 17 & & \\
\hline & R7B4 & $17 / 07 / 2006$ & $06: 52$ & $00: 14$ & 6 & & \\
\hline & R7B5 & $17 / 07 / 2006$ & 07:07 & $00: 22$ & 9 & & \\
\hline & R7B6 & $17 / 07 / 2006$ & $07: 30$ & 01:19 & 7 & & \\
\hline
\end{tabular}

by the winds produced by the propagation of squall lines, explaining the North-East winds observed during MCS. The TEOM measurements show that the aerosol mass concentrations reach values around $0.5 \mathrm{~g} \mathrm{~m}^{-3}$ during the dust outbreaks, whereas the average background concentrations are around $140 \mu \mathrm{g} \mathrm{m}^{-3}$, confirming a high dust local production (Sow et al., 2009).

Mesoscale convective cloud systems consist of a combination of convective and stratiform precipitations (Houze, 1997). The typical precipitation pattern of a MCS is characterized by a heavy convective precipitation followed by a slow stratiform rainfall. Figure 3 displays the rain intensity of the collected events. The precipitation distribution of rain R3 shows only a stratiform structure, whereas rains $\mathrm{R} 1$ and R2 seem to be mainly convective precipitations. The other events combine the two types of rainfall more or less in agreement with the typical pattern. The comparison between the sample timing and rain intensity show that the same number of bottle samples (for example RXB3) corresponds as well to convective precipitations as to stratiform rainfall. 


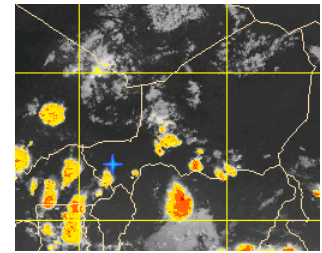
$13 / 07$ to $19: 00$ UTC

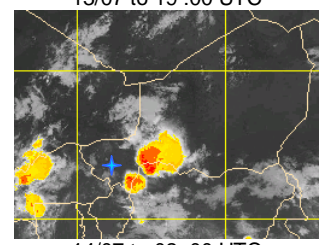
14/07 to $02: 00$ UTC

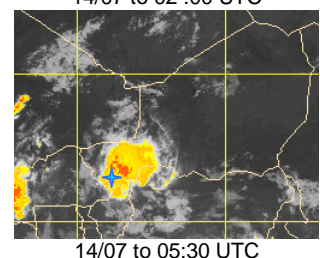

14/07 to $05: 30$ UTC

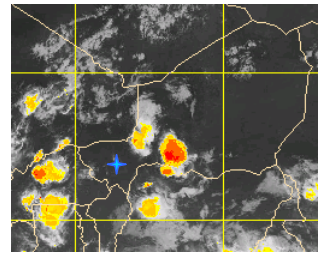
13/07 to $23: 00$ UTC

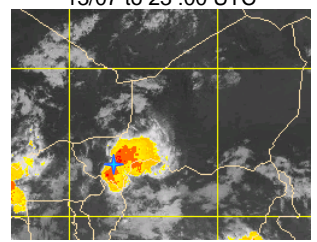
14/07 to $04: 00$ UTC

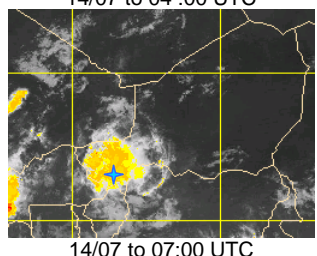

14/07 to $07: 00$ UTC

Fig. 1. Meteosat images from convective system developing for the 14 July 2006, the Banizoumbou station is marked by a blue star.

\subsection{Total elemental composition of rainwater}

The sequential study of single precipitation events shows that the aerosol loadings in the samples of the beginning of rain event are very high when compared to the one of the following samples (Table 1). More precisely, from 40 to $90 \%$ of the particulate mass deposition occurs in the first sequential sample. This high percentage of deposed particles can be attributed to the washing-out by the rain of the dust lifted by the convective systems. In order to discriminate the samples influenced by the wash-out from those representative of precipitating cloud, we compare the total elemental composition of sequential rainwater samples with the local dust characteristics issued by Formenti et al. (2008) (e.g. for the rain R6, Fig. 4). The results of the elemental composition of Sahelian dust compared with those of Saharan dust and of other aerosols measured in Western Africa (biomass burning and sea salt) show that local Sahelian dust is richest in Fe and $\mathrm{Si}$, whereas its $\mathrm{Na}$ and $\mathrm{Ca}$ contents are the lowest observed (McConnell et al., 2008). In the case of the rain R6, Na, $\mathrm{Ca}, \mathrm{Fe}$ and $\mathrm{Si}$ contents are close to those expected for local dust in the first two samples, but their abundance is different (either higher or lower) in the following samples, emphasizing the contribution of other aerosol source(s) during the rain event. These observations confirm a clear influence of local dust at the initial stage of the precipitation, then the effect of below cloud scavenging seems to become negligible in the other sequential samples. For these last samples, the total elemental composition can therefore be considered as characteristic of the remotely incorporated aerosols in precipitating

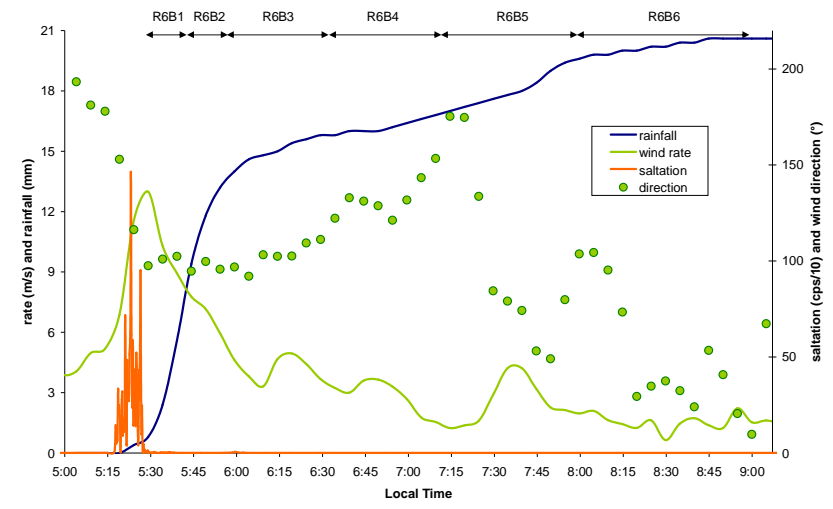

Fig. 2. Surface typical features of the propagating MCS in the case of the rain R6 (14 July 2006): at the leading edge of the MCS, downdraughts from the convective cells produce an increasing of surface wind and hence a high wind erosion with important dust emission, then to the rear of the MCS front, severe rain occurs, inhibiting dust atmospheric charge. Here, the different successive time of rainwater sampling are represented for the rain R6 (R6B1 to R6B6).

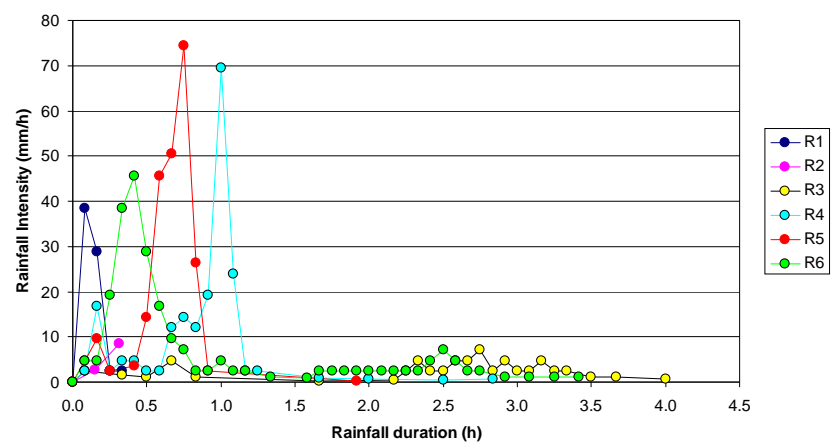

Fig. 3. Precipitation intensity $(\mathrm{mm} / \mathrm{h})$ for the different collected events.

convective cloud. Thus, for the following discussion on the variation of elemental composition, we will consider only the samples identified as not affected by the washing-out of local dust (Table 1, no sample for R2).

The mean elemental composition of the end of rains (preselected samples) is illustrated in Table 2. However, the comparison of our results on the estimated mass percentage with others works based on other methods of mass calculation could be biased. For facilitating comparison with other published data, the mean elemental $\mathrm{Al}$ ratios are also reported in Table 2. The results show that for all the studied rains, the elemental ratios are consistent with the typical values of African dust samples (Blanco et al., 2003; Formenti et al., 2008; Lafon et al., 2006). The presence of biomass burning aerosols has been identified jointly with dust in the monsoon atmosphere over Niger (Crumeyrolle et al., 2008), probably imported from southern hemisphere African Easterly Jet activity (Mari et al., 2008). In the rain samples, the K/Al ratio 
Table 2. Mean elemental total composition and mean elemental Al ratio for the samples not influenced by local dust wash-out.

\begin{tabular}{|c|c|c|c|c|c|c|c|c|c|c|c|c|}
\hline & \multicolumn{2}{|c|}{$\begin{array}{c}\mathrm{R} 1 \\
\% \operatorname{mass}( \pm)\end{array}$} & \multicolumn{2}{|c|}{$\begin{array}{c}\mathrm{R} 3 \\
\% \text { mass }( \pm)\end{array}$} & \multicolumn{2}{|c|}{$\begin{array}{c}\mathrm{R} 4 \\
\% \text { mass }( \pm)\end{array}$} & \multicolumn{2}{|c|}{$\begin{array}{c}\mathrm{R} 5 \\
\% \operatorname{mass}( \pm)\end{array}$} & \multicolumn{2}{|c|}{$\begin{array}{c}\text { R6 } \\
\% \text { mass }( \pm)\end{array}$} & \multicolumn{2}{|c|}{$\begin{array}{c}\mathrm{R} 7 \\
\% \text { mass }( \pm)\end{array}$} \\
\hline $\mathrm{Na}$ & $0.5 \%$ & $0.0 \%$ & $2.8 \%$ & $3.5 \%$ & $2.4 \%$ & $2.8 \%$ & $1.8 \%$ & $2.6 \%$ & $2.5 \%$ & $2.9 \%$ & $1.3 \%$ & $2.2 \%$ \\
\hline $\mathrm{K}$ & $1.3 \%$ & $0.1 \%$ & $3.4 \%$ & $2.9 \%$ & $2.3 \%$ & $0.9 \%$ & $1.8 \%$ & $0.9 \%$ & $1.6 \%$ & $0.8 \%$ & $1.5 \%$ & $1.0 \%$ \\
\hline $\mathrm{Mg}$ & $0.5 \%$ & $0.1 \%$ & $1.0 \%$ & $0.7 \%$ & $1.0 \%$ & $0.4 \%$ & $0.8 \%$ & $0.4 \%$ & $1.1 \%$ & $0.4 \%$ & $0.9 \%$ & $0.6 \%$ \\
\hline $\mathrm{Ca}$ & $1.2 \%$ & $0.2 \%$ & $2.4 \%$ & $1.8 \%$ & $4.1 \%$ & $3.7 \%$ & $2.0 \%$ & $1.7 \%$ & $3.6 \%$ & $2.8 \%$ & $1.8 \%$ & $1.7 \%$ \\
\hline $\mathrm{Fe}$ & $4.3 \%$ & $0.2 \%$ & $3.4 \%$ & $1.1 \%$ & $3.6 \%$ & $0.4 \%$ & $3.9 \%$ & $1.4 \%$ & $3.4 \%$ & $0.3 \%$ & $2.7 \%$ & $1.0 \%$ \\
\hline $\mathrm{Si}$ & $14.8 \%$ & $0.3 \%$ & $14.7 \%$ & $3.0 \%$ & $14.5 \%$ & $1.2 \%$ & $13.8 \%$ & $3.5 \%$ & $14.0 \%$ & $0.6 \%$ & $9.8 \%$ & $4.9 \%$ \\
\hline $\mathrm{Ti}$ & $0.7 \%$ & $0.1 \%$ & $0.9 \%$ & $0.3 \%$ & $0.7 \%$ & $0.1 \%$ & $0.7 \%$ & $0.2 \%$ & $0.6 \%$ & $0.1 \%$ & $0.4 \%$ & $0.2 \%$ \\
\hline \multirow[t]{2}{*}{$\mathrm{P}$} & $0.1 \%$ & $0.0 \%$ & $0.1 \%$ & $0.0 \%$ & $0.1 \%$ & $0.1 \%$ & $0.1 \%$ & $0.0 \%$ & $0.1 \%$ & $0.1 \%$ & $0.1 \%$ & $0.0 \%$ \\
\hline & \multicolumn{2}{|c|}{$\mathrm{X} / \mathrm{Al}( \pm)$} & \multicolumn{2}{|c|}{$\mathrm{X} / \mathrm{Al}( \pm)$} & \multicolumn{2}{|c|}{$\mathrm{X} / \mathrm{Al}( \pm)$} & \multicolumn{2}{|c|}{$\mathrm{X} / \mathrm{Al}( \pm)$} & \multicolumn{2}{|c|}{$\mathrm{X} / \mathrm{Al}( \pm)$} & \multicolumn{2}{|c|}{$\mathrm{X} / \mathrm{Al}( \pm)$} \\
\hline $\mathrm{Na}$ & 0.093 & 0.001 & 0.4 & 0.5 & 0.3 & 0.5 & 0.3 & 0.5 & 0.4 & 0.5 & 0.2 & 0.4 \\
\hline $\mathrm{K}$ & 0.24 & 0.02 & 0.4 & 0.2 & 0.3 & 0.2 & 0.3 & 0.2 & 0.3 & 0.1 & 0.3 & 0.2 \\
\hline $\mathrm{Mg}$ & 0.10 & 0.01 & 0.18 & 0.08 & 0.14 & 0.08 & 0.14 & 0.08 & 0.19 & 0.07 & 0.2 & 0.1 \\
\hline $\mathrm{Ca}$ & 0.23 & 0.03 & 0.7 & 0.7 & 0.4 & 0.3 & 0.4 & 0.3 & 0.7 & 0.5 & 0.3 & 0.3 \\
\hline $\mathrm{Fe}$ & 0.78 & 0.04 & 0.65 & 0.07 & 0.7 & 0.2 & 0.7 & 0.2 & 0.62 & 0.05 & 0.5 & 0.2 \\
\hline $\mathrm{Si}$ & 2.70 & 0.06 & 2.6 & 0.2 & 2.5 & 0.6 & 2.5 & 0.6 & 2.54 & 0.11 & 1.8 & 0.9 \\
\hline $\mathrm{Ti}$ & 0.13 & 0.01 & 0.12 & 0.02 & 0.12 & 0.04 & 0.12 & 0.04 & 0.11 & 0.01 & 0.07 & 0.04 \\
\hline $\mathrm{P}$ & 0.013 & 0.002 & 0.01 & 0.01 & 0.014 & 0.004 & 0.014 & 0.004 & 0.02 & 0.01 & 0.012 & 0.004 \\
\hline
\end{tabular}

ranges from 0.24 to 0.4 and is slightly larger than the previously reported value ca. 0.2 for mineral dust (Chiapello et al., 1997; Formenti et al., 2003, 2008). However, the K/Al ratio does not reach the large value (0.52) observed in the dustmixed biomass burning during the dry season (Formenti et al., 2008; Paris et al., 2010). As a consequence, it seems that the biomass burning K-enriched particles have a too small influence on the total elemental composition to create significant departures from the dust original composition. Because the southwesterly monsoon winds could also enable marine import from Guinean gulf and alter the aerosol composition, we have also studied the $\mathrm{Na} / \mathrm{Al}$ ratio. Previously published data show a large range of potential values (from 0.04 to 0.5 , Formenti et al., 2008) consistent with those measured in our rain samples. Moreover, no correlation is observed between the $\mathrm{Na}^{+}$and $\mathrm{Cl}^{-}$concentrations in the dissolved phase of the rainwater (see Sect. 3.3., Table 3), indicating insignificant influence of marine aerosols. Biogenic emissions, and the associated secondary organic aerosols which have frequently been observed in this season over West Africa (Capes et al., 2009), could also contribute to the aerosol load in the rain samples. However, the observed mass concentrations of organic submicron aerosols (median $1.07 \mu \mathrm{g} \mathrm{m}^{-3}$, Capes et al., 2009) are negligible compared to the total aerosol mass measured in Banizoumbou in summer $\left(140 \mu \mathrm{g} \mathrm{m}^{-3}\right.$ on average, see Sect. 3.1.). Finally, scanning electron microscopic observations of the rain filters do not reveal any mixing of aerosol types or the presence of any component other than dust. As a result, the major contribution in the total elemental composition can be attributed to mineral dust, pointing out that

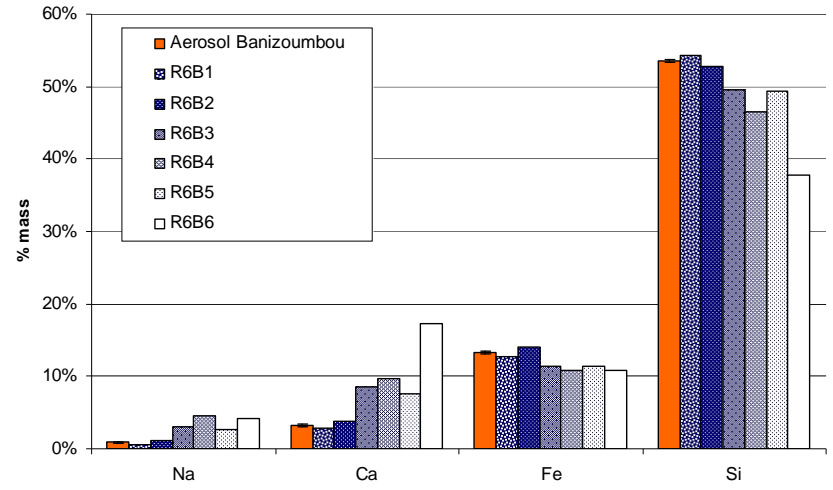

Fig. 4. Comparaison between total elemental content in collected samples for the rain R6 (14 July 2006) and in emitted local dust extracted from Formenti et al. (2008).

dust are initially incorporated in convective cloud. In turn, this suggests that dust is incorporated in the convective and stratiform clouds, either as CCN or by rain-out, and reinforces the assumption of the in-cloud processing of dust in the convective system (Crumeyrolle et al., 2008; Matsuki et al., 2010).

Over West Africa, dust is transported in summertime at altitudes of a few $\mathrm{km}$ in the northeasterly dry Harmattan layer (Lothon et al., 2008; Bou Karam et al., 2009). The presence of dust at lower altitudes may be due to a combination of fresh emissions from local dust sources and sedimentation of dust from upper plumes (Ben-Ami et al., 2009). Therefore, the dust found in the convective clouds could either originate 
Table 3. Median chemical composition of dissolved phase of each collected rains during AMMA SOP 1 and 2.

\begin{tabular}{|c|c|c|c|c|c|c|c|c|c|c|c|c|c|c|}
\hline \multirow{3}{*}{$\frac{\mu \mathrm{eq} / \mathrm{L}}{\mathrm{H}^{+}}$} & \multicolumn{2}{|c|}{ R1 } & \multicolumn{2}{|c|}{$\mathrm{R} 2$} & \multicolumn{2}{|c|}{$\mathrm{R} 3$} & \multicolumn{2}{|c|}{$\mathrm{R} 4$} & \multicolumn{2}{|c|}{ R5 } & \multicolumn{2}{|c|}{ R6 } & \multicolumn{2}{|c|}{ R7 } \\
\hline & \multicolumn{2}{|c|}{ concentration $( \pm)$} & \multicolumn{2}{|c|}{ concentration $( \pm)$} & \multicolumn{2}{|c|}{ concentration $( \pm)$} & \multicolumn{2}{|c|}{ concentration $( \pm)$} & \multicolumn{2}{|c|}{ concentration $( \pm)$} & \multicolumn{2}{|c|}{ concentration $( \pm)$} & \multicolumn{2}{|c|}{ concentration $( \pm)$} \\
\hline & 3.89 & 0.4201 & 6.76 & 0.57 & 4.24 & 0.29 & 6.00 & 0.52 & 6.73 & 0.37 & 11.53 & 0.4795 & 6.26 & 0.13 \\
\hline $\mathrm{Na}^{+}$ & 29.7 & 4.9 & 45.2 & 27.9 & 35.0 & 80.3 & 27.1 & 27.3 & 17.6 & 20.2 & 7.6 & 5.8 & 5.1 & 7.6 \\
\hline $\mathrm{K}+$ & 11.9 & 4.3 & 57.7 & 57.3 & 33.7 & 45.2 & 11.1 & 7.4 & 8.4 & 7.9 & 2.3 & 1.2 & 2.3 & 2.6 \\
\hline $\mathrm{Mg}^{2+}$ & 34.0 & 2.4 & 66.7 & 27.2 & 34.8 & 18.9 & 13.6 & 4.3 & 11.0 & 4.8 & 4.7 & 1.1 & 4.7 & 2.4 \\
\hline $\mathrm{Ca}^{2+}$ & 49.2 & 6.8 & 71.8 & 10.3 & 41.1 & 26.8 & 39.9 & 17.9 & 29.0 & 11.0 & 16.4 & 4.4 & 8.7 & 3.1 \\
\hline $\mathrm{NH}_{4}^{+}$ & 2.6 & 1.9 & 3.2 & 1.3 & 2.5 & 0.6 & 11.3 & 5.2 & 10.5 & 2.3 & 14.5 & 8.5 & 9.3 & 4.1 \\
\hline $\mathrm{CH}_{3} \mathrm{COO}^{-}$ & 0.0 & 0.0 & 0.0 & 0.0 & 0.3 & 0.4 & 5.4 & 8.5 & 6.1 & 14.7 & 12.6 & 7.5 & 6.6 & 3.5 \\
\hline $\mathrm{C}_{2} \mathrm{H}_{5} \mathrm{COO}^{-}$ & 0.0 & 0.0 & 0.0 & 0.0 & 1.6 & 3.1 & 0.0 & 0.1 & 0.4 & 0.5 & 0.3 & 0.2 & 0.0 & 0.1 \\
\hline $\mathrm{HCOO}^{-}$ & 0.1 & 0.0 & 0.2 & 0.1 & 0.3 & 0.3 & 8.1 & 9.1 & 11.8 & 14.6 & 13.3 & 3.2 & 6.2 & 2.6 \\
\hline $\mathrm{CH}_{3}-\mathrm{CO}-\mathrm{COO}^{-}$ & 0.3 & 0.1 & 0.2 & 0.0 & 0.2 & 0.2 & 0.2 & 0.1 & 0.2 & 0.0 & 0.2 & 0.1 & 0.2 & 0.1 \\
\hline $\mathrm{C}_{2} \mathrm{O}_{4}^{2-}$ & 0.5 & 0.0 & 0.4 & 0.0 & 1.3 & 0.7 & 0.6 & 0.2 & 3.6 & 1.2 & 1.9 & 0.4 & 1.2 & 0.4 \\
\hline $\mathrm{F}^{-4}$ & 2.0 & 0.9 & 0.4 & 0.2 & 4.8 & 4.1 & 0.5 & 0.6 & 3.0 & 2.8 & 0.7 & 0.5 & 0.9 & 1.2 \\
\hline $\mathrm{Cl}^{-}$ & 33.5 & 7.2 & 29.2 & 17.0 & 27.9 & 22.1 & 13.7 & 16.7 & 17.5 & 19.1 & 13.3 & 20.2 & 8.8 & 20.5 \\
\hline $\mathrm{NO}_{2}^{-}$ & 0.8 & 0.6 & 0.5 & 0.2 & 0.1 & 0.1 & 0.1 & 0.1 & 0.2 & 0.2 & 0.1 & 0.1 & 0.3 & 0.4 \\
\hline $\mathrm{Br}^{-}$ & 0.3 & 0.1 & 0.2 & 0.1 & 0.1 & 0.1 & 0.2 & 0.0 & 0.2 & 0.1 & 0.1 & 0.0 & 0.1 & 0.0 \\
\hline $\mathrm{NO}_{3}^{-}$ & 42.3 & 12.2 & 45.5 & 18.4 & 17.2 & 28.0 & 13.5 & 8.6 & 19.6 & 25.3 & 11.1 & 7.3 & 7.0 & 2.8 \\
\hline $\mathrm{SO}_{4}^{2-}$ & 55.3 & 2.4 & 61.5 & 3.3 & 85.1 & 81.4 & 59.6 & 49.2 & 24.7 & 30.9 & 8.9 & 14.0 & 7.1 & 13.5 \\
\hline $\mathrm{PO}_{4}^{3-}$ & 1.3 & 0.3 & 3.0 & 1.8 & 1.0 & 0.8 & 0.7 & 0.6 & 0.9 & 0.6 & 0.3 & 0.2 & 0.7 & 0.0 \\
\hline$\Sigma$ cation & 131.3 & & 251.4 & & 151.4 & & 109.1 & & 83.2 & & 57.1 & & 36.5 & \\
\hline$\Sigma$ anion & 136.4 & & 141.0 & & 139.8 & & 102.5 & & 88.1 & & 62.9 & & 39.3 & \\
\hline ionic budget & $-1.9 \%$ & & $28.1 \%$ & & $4.0 \%$ & & $3.1 \%$ & & $-2.8 \%$ & & $-4.9 \%$ & & $-3.7 \%$ & \\
\hline $\mathrm{pH}$ & 5.4 & & 5.2 & & 5.4 & & 5.2 & & 5.2 & & 4.9 & & 5.2 & \\
\hline $\begin{array}{l}\text { organic part } \\
\text { on acidity }\end{array}$ & $27.9 \%$ & & $26.4 \%$ & & $41.0 \%$ & & $53.5 \%$ & & $47.5 \%$ & & $68.9 \%$ & & $67.9 \%$ & \\
\hline
\end{tabular}

from the Harmattan layer or be incorporated locally during the formation of the convective system. Previous studies of elemental composition of dust in Niger during the dry season have shown that locally-produced dust is characterized by low $\mathrm{Ca}$ contents, but also larger $\mathrm{Si}, \mathrm{Al}, \mathrm{Fe}$ and $\mathrm{Ti}$ contents than the dust advected from Northern Saharan sources (Formenti et al., 2008; Rajot et al., 2008). The Northern Saharan dust is usually enriched in $\mathrm{Ca}$ and $\mathrm{Mg}$, because carbonates such as calcite $\left(\mathrm{CaCO}_{3}\right)$ and dolomite $\left(\mathrm{CaMg}\left(\mathrm{CO}_{3}\right)_{2}\right)$ are mainly found in the North African deserts. The latitudinal inhomogeneous distribution of carbonate minerals in the Saharan soils leads to a high North-South gradient of dust $\mathrm{Ca}$ content (Kandler and Schutz, 2007). Hence, the $\mathrm{Ca} / \mathrm{Al}$ ratio ranges from 0.2 for dust produced in the Sahelian belt and South of the Sahara to 2 for dust originating from the North-western Sahara (Bergametti et al., 1989; Blanco et al., 2003; Chiapello et al., 1997; Formenti et al., 2008; Lafon et al., 2006; McConnell et al., 2008). For a same source, measurements show that higher ratios are generally obtained for the locations closest to the source, due to preferential settling of coarse carbonate particles during transport (Blanco et al., 2003). Mc Connell et al. (2008) also emphasize a seasonal evolution of the $\mathrm{Ca} / \mathrm{Al}$ ratio in the Harmattan layer, with $\mathrm{Ca} / \mathrm{Al}$ ratio substantially lower in summer $(0.5 \pm 0.2)$ than during the dry season $(1.1 \pm 0.4)$, indicating that the summer samples correspond to sources located closer to the southern Sahara than in winter. As compared to local uplifted dust, the samples collected at the end of the rain, are enriched in
$\mathrm{Na}$ and $\mathrm{Ca}$ and poorer in $\mathrm{Fe}$ and $\mathrm{Si}$. This indicates a Saharan origin for the dust present in the rainwater (Fig. 4). $\mathrm{The} \mathrm{Ca} / \mathrm{Al}$ ratios of the rain samples are in the same order of magnitude (ranging from 0.2 to 0.7 ) than in the summer Harmattan layer. The $\mathrm{Na} / \mathrm{Al}$ value (around 0.3 ) is also consistent with the ratio observed in the Harmattan layer in wintertime (Formenti et al., 2008). For testing the assumption that the in-cloud incorporation of local dust is more efficient in convective conditions, we compare the total elemental composition of non-squall MCS (R1 and R5) to the one of squall-line convective systems (R3, R4, R6, R7) (Table 2). No significant difference of mean total elemental composition can be detected between the two types of rain events. This suggests that the dust collected in rainwater mainly originates from the Harmattan layer. The direct measurements performed by Matsuki et al. (2010) in the stratiform part of convective clouds also revealed a large proportion of carbonates in the dust, confirming the Saharan sources influence and hence the Harmattan layer origin. Similarly, the mean composition of R7, which formed in the South of Niger in July, is not significantly different from the one of the other SLMCS, which formed over the Airr region during SOP $1 \& 2$. This denotes a regional and temporal homogeneity of the dust composition in the Harmattan layer.

The activation of Saharan southern and Sahelian sources in summer is a well-known phenomenon, due to the synoptic conditions over West Africa (Karyampudi et al., 1999; Schepanski et al., 2009). However, the contribution of 
various southern sources in the elevated dust layer is not well-established. In particular, the partition between Sahelian and Saharan dust is debated (Tegen and Fung, 1995). As already mentioned above, Mc Connell et al. (2008) conclude to a predominance of Southern Saharan source influencing the Harmattan layer in summer. In first approach the $\mathrm{Ca} / \mathrm{Al}$ ratio values seem to confirm the importance of South-eastern Saharan dust sources (Aïr, Ténéré or Chad) in comparison to Sahelian sources and is in agreement with the conception of the AEJ being a provider of dust for the Harmattan layer (Bou Karam et al., 2008). Even if Si is generally found in similar proportions in the Sahelian and Saharan dust sources, particularly high Si/Al contents (around 4) are observed in the dust plumes originating from the Bodélé depression because of the suspended diatoms they contain (Formenti et al., 2008; Washington et al., 2006). Diatoms are algae encased in a silica cell wall, originally present in the Mega-Lake Chad before drought, and now make-up the surface of the Bodélé Depression. In the case of rain filters, these diatoms are detected by microscopic analysis, confirming the presence of extra-Sahelian dust, whatever the type and the developing zone of the MCS (Fig. 5). However, the Chadian source is not predominant since the mean ratios $\mathrm{Si} / \mathrm{Al}$ found in rainwater are close to the typical values of 'non-Bodélé' African dust (Formenti et al., 2008). Moreover, the rich-in-carbonate south-eastern Saharan sources are probably the major contributors.

\subsection{Variation of dissolved phase composition}

A sequential study of given precipitation event shows that ionic concentrations are quasi-stable throughout it (not shown). This stability in ionic composition points out the low wash-out effect and the low influence of other phenomenon like gaseous dissolution during the rain event. Consequently, the results of the ionic composition can be discussed cumulatively for one rain. These observations also enable us to conclude that the ionic composition is mainly determined by the chemical processes taking place in the convective clouds.

Table 2 shows the median dissolved concentrations of each rain sample. The dominant ions are $\mathrm{Ca}^{2+}$ and $\mathrm{Mg}^{2+}$, nitrate $\left(\mathrm{NO}_{3}^{-}\right)$, sulphate $\left(\mathrm{SO}_{4}^{2-}\right)$ and chloride $\left(\mathrm{Cl}^{-}\right)$. They are all present in low concentrations $(<70 \mu \mathrm{eq} / \mathrm{L})$. These observations are in agreement with the mean chemical composition of Banizoumbou rains of Galy-Lacaux et al. (2009), indicating a high influence of terrigeneous ions and limited marine or anthropogenic contribution, as also concluded from the total elemental composition. However, the data set is heterogeneous overall as discussed below. For the comparison of the cations and anions, an ion balance was calculated. This ion balance is quasi-equilibrated for most rains, except rain R2 in which a large deficit in anions is observed. The first sample of this rain contains a very high particulate load (Table 1 : around $3 \mathrm{~g} / \mathrm{L}$ for a median value of $250 \mathrm{mg} / \mathrm{L}$ ). A potential contamination of the dissolved phase by fine dust particles
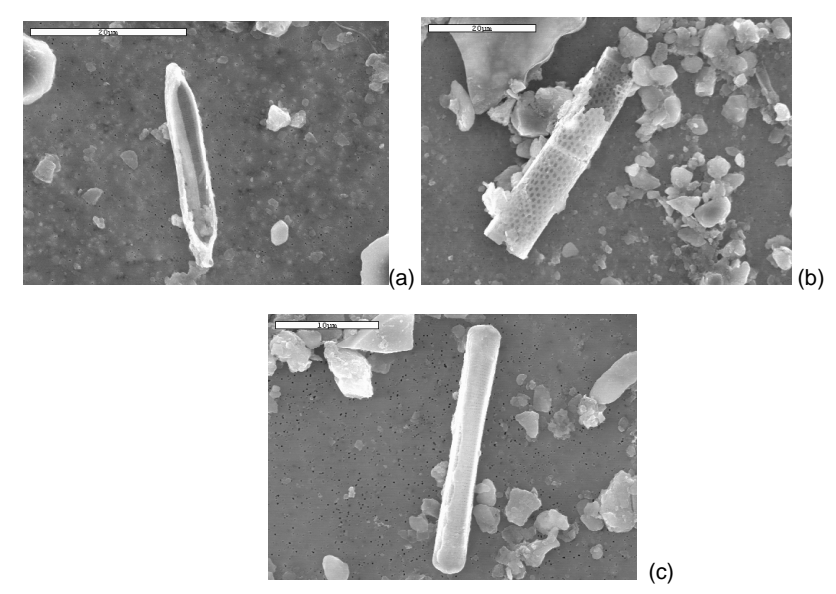

Fig. 5. SEM images of aerosols found on the rainwater filters: illustration of the Bodélé diatoms presence in the R3B4 samples originating from MCS developed in the North of Niger (a) and in the R7B5 samples colleted during SLMCS developed in the South of Niger (b, c).

could explain this disequilibrium. Indeed, these particles are analysed for cations in ICP-AES, but not for anions in IC.

The median $\mathrm{pH}$ of the rain samples is 5.20, but exhibits a wide range of values, from acid (3.61) to alkaline $\mathrm{pH}$ (6.06). Precipitation $\mathrm{pH}$ in Banizoumbou is usually alkaline (median $\mathrm{pH}$ around 6) via neutralisation by carbonates $\left(\mathrm{CaCO}_{3}\right)$ from mineral dust (Galy-Lacaux et al., 2009). Despite the presence of dust particles rich in calcite (see above Sect. 3.2), only $20 \%$ of our samples have a $\mathrm{pH}>5.5$. Thus, the collected rains do not appear strongly affected by the buffering capacity of dust. On the contrary, the measured values are typical of unpolluted tropical regions (Eklund et al., 1997; Heartsill-Scalley et al., 2007). Even if no gradient of $\mathrm{pH}$ is observed on our samples, the acidity is associated with nitrate and sulphate concentrations in the June samples (R1 to R3) whereas in July the acidity of the collected rains (R4 to R7) is mainly controlled by the organic species, representing up to $69 \%$ of the precipitation acidity (Table 2). These inorganic or organic acids could neutralise the buffering effect of dust. The transition from predominance of inorganic ions to one of organic ions observed on the acidity reflects the general trend of the anionic composition of rains. Figure 6 illustrates the relative contribution of the anionic composition of the different rainwater samples. The dominant species in the rainwater are inorganic anions with a contribution superior to $90 \%$ in the first rains then decreases around $60 \%$ for the last rains. One reason of the decrease of the inorganic part and subsequent increase of the relative organic part is the decrease of concentrations of the major inorganic anions (sulphate, nitrate and chloride) from around $50 \mu \mathrm{eq} / \mathrm{L}$ to $10 \mu \mathrm{eq} / \mathrm{L}$. Inversely, the concentrations of acetate $\left(\mathrm{CH}_{3} \mathrm{COO}^{-}\right)$and formate $\left(\mathrm{HCOO}^{-}\right)$are correlated $\left(R^{2}=0.73\right)$ and increase from nearly zero in the first 


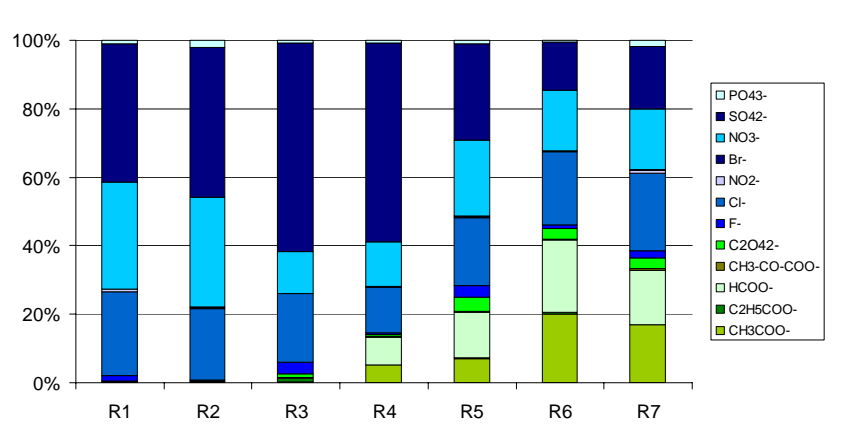

Fig. 6. Distribution of the median equivalent contribution to the measured anion load $(\%)$ of the rainwater samples. The organic anions appear in green and the inorganic anions in blue.

samples to around $10 \mu \mathrm{Eq} / \mathrm{L}$ at the end of the sampling period. The third main organic anion is oxalate $\left(\mathrm{C}_{2} \mathrm{O}_{4}^{2-}\right)$, the concentrations of which increase also in July in comparison to June but stays low (less to $4 \mu \mathrm{eq} / \mathrm{L}$ ). The concentrations measured in the July samples (R4 to R7) are representative of the mean anionic concentrations at Banizoumbou and for the West African wet Savannah and tropical forest reviewed by Galy-Lacaux et al. (2009), whereas the rains collected in June (R1 to R3) are richer in inorganic anions and characterized by very low values of the organic species. The contribution of acetic and formic acids to the precipitation acidity (around 60\%) is related to a biogenic influence (Seco et al., 2007). Based on the biogenic origin of acetate and formate and FAPAR profiles (Fraction of Absorbed Photosynthetically Active Radiation), Galy-Lacaux et al. (2009) conclude that the organic acidity content is mainly controlled at the beginning of the wet season by the biogenic emissions related to the vegetation cycle in the Sahel. However, the late arrival of the 2006 monsoon led to negative soil moisture anomalies over the Sahel inducing similar vegetation cover anomalies (Janicot et al., 2008). Moreover, the mineral dust content in the Sahelian belt in 2006 shows higher values in June, and a decrease shifted later in the wet season revealing a later inhibition of local dust emission due to late vegetation development. In these conditions, the passage of the raining clouds liberates large amounts of $\mathrm{NO}_{\mathrm{x}}$, precursor of nitrate, from the soils up to the atmosphere (Stewart et al., 2008) and hence can explain the large part of this compound in June. Our results clearly display this delay of the vegetation development since the biogenic influence on the chemical composition of rain appears only in the samples collected in July. Thus, the rains collected in June, before the onset of the monsoon, present the anionic composition signature of the Sahelian air masses.

\section{Implication of convective system on dust transport and deposition and their impacts}

The MCS constitute a predominant feature of the West Africa meteorology during the wet season. Our sequential study of precipitating events shows that the total chemical composition of rainwater is initially controlled by the wash-out of local uplifted dust in the first $\mathrm{mm}$ of rainfall. Then the total chemical composition is always dominated by the dust incorporated in the convective clouds from the Harmattan Layer by rain-out or as CCN. Our results also show a spatiotemporal homogeneity in the chemical composition of the dust incorporated in the MCS, due to a prevailing influence of Saharan South-eastern sources (Ténéré, the Bodélé depression,...). Thus, the precipitating convective systems act as efficient processes to remove dust from the upper Harmattan layer and to carry and depose dust from source to remote areas. The rainfall variability over the Atlantic Ocean, and notably cyclone activity, are significantly modulated by the precipitation features of the West African monsoon (Maloney and Shaman, 2008). The deposition of mineral dust is a major source of nutrients for open oceans and wet deposition is more efficient at supplying bioavailable nutrients to the phytoplankton than dry deposition. Consequently, the input of dust by the precipitating MCS from West Africa during the wet season over the Atlantic Ocean could prove to be the major contribution of atmospheric nutrient deposition in this region. The impoverishment of the Harmattan layer in dust concentrations by the MCS could also modify the regional solar and infrared radiative budget.

Our results show also that the ionic composition of rainwater is little influenced by the local rainwater compounds. The inorganic anions $\left(\mathrm{NO}_{3}^{-}\right.$and $\left.\mathrm{SO}_{4}^{2-}\right)$ are predominant at the beginning of the wet season, then the organic anions (acetate and formate) of biogenic origin become predominant with the vegetation development, after the monsoon jump. Thus, the chemical environment of dust in the convective clouds varies with the advancement of the wet season. Thus, as with dust, convective systems constitute an efficient provider of organic carbon for the terrestrial and marine biospheres. The wet deposition of organic carbon being a critical point in the carbon budget over the oceans (Jurado et al., 2008), the MCS could play an important role in the global carbon cycle.

In-cloud reactivity is also known to favour the uptake of soluble species on mineral dust particles (Desboeufs et al., 2001; Sullivan et al., 2007). The internal mixing between dust and nitrate has been observed by microscopic method on aerosol filters collected before and after convective system during the monsoon (Crumeyrolle et al., 2008; Matsuki et al., 2010). Our results suggest that this mixing could also occur with organic compounds, which are rarely observed by microscopic analysis. Recent works show that the mixing between dust and organic species favour the solubility and hence bioavailabilty of iron, a nutrient essential to phytoplankton growth, in the atmospheric deposition (Chen and 
Siefert, 2004). Thus, by deposing jointly dust and organic species, the precipitating MCS could also impact marine productivity in the Atlantic Ocean.

Acknowledgements. Based on a French initiative, AMMA was built by an international scientific group and is currently funded by a large number of agencies, especially from France, the United Kingdom, the United States, and Africa. It has been the beneficiary of a major financial contribution from the European Community Sixth Framework Research Programme. Detailed information on scientific coordination and funding is available on the AMMA International Web site at www.amma-international.org. This work was funded by the EU and by the UK Natural Environment Research Council through the AMMA-UK Consortium grant and the National Centre for Atmospheric Science.

The authors are thankful to Nicolas Mouget and Aliko Maman for their precious help during the field campaign, and Stephane Alfaro for his useful comments.

Edited by: J. Williams

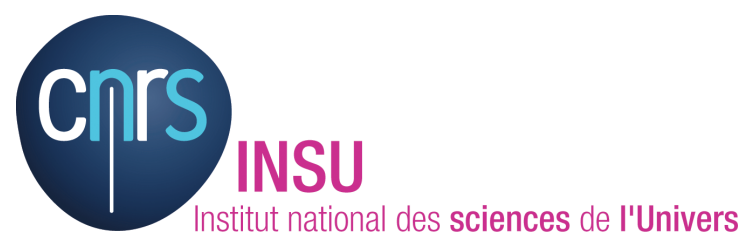

The publication of this article is financed by CNRS-INSU.

\section{References}

Ben-Ami, Y., Koren, I., and Altaratz, O.: Patterns of North African dust transport over the Atlantic: winter vs. summer, based on CALIPSO first year data, Atmos. Chem. Phys., 9, 7867-7875, doi:10.5194/acp-9-7867-2009, 2009.

Bergametti, G., Gomes, L., Coude-Gaussen, G., Rognon, P., and Coustumer, M.-N. L.: African Dust Observed over Canary Islands: Source-Regions Identification and Transport Pattern for some Summer Situations, J. Geophys. Res., 94, 14855-14864, 1989.

Blanco, A., Dee Tomasi, F., Filippo, E., Manno, D., Perrone, M. R., Serra, A., Tafuro, A. M., and Tepore, A.: Characterization of African dust over southern Italy, Atmos. Chem. Phys., 3, 21472159, doi:10.5194/acp-3-2147-2003, 2003.

Bou Karam, D., Flamant, C., Knippertz, P., Reitebuch, O., Pelon, J., Chong, M., and Dabas, A.: Dust emissions over the Sahel associated with the West African monsoon intertropical discontinuity region: A representative case-study, Q. J. Roy. Meteorol. Soc., 134, 621-634, 2008.

Capes, G., Murphy, J. G., Reeves, C. E., McQuaid, J. B., Hamilton, J. F., Hopkins, J. R., Crosier, J., Williams, P. I., and Coe, H.: Secondary organic aerosol from biogenic VOCs over West Africa during AMMA, Atmos. Chem. Phys., 9, 3841-3850, doi:10.5194/acp-9-3841-2009, 2009.

Chen, Y. and Siefert, R. L.: Seasonal and spatial distributions and dry deposition fluxes of atmospheric total and labile iron over the tropical and subtropical North Atlantic Ocean, J. Geophys. Res., 109, 1-14, 2004.

Chiapello, I., Bergametti, G., Chatenet, B., Bousquet, P., Dulac, F., and Soares, E. S.: Origins of African dust transported over the northeastern tropical Atlantic, J. Geophys. Res., 102(D12), 13701-13709, doi:10.1029/97jd00259, 1997.

Crumeyrolle, S., Gomes, L., Tulet, P., Matsuki, A., Schwarzenboeck, A., and Crahan, K.: Increase of the aerosol hygroscopicity by cloud processing in a mesoscale convective system: a case study from the AMMA campaign, Atmos. Chem. Phys., 8, 6907-6924, doi:10.5194/acp-8-6907-2008, 2008.

Desboeufs, K. V., Losno, R., and Colin, J. L.: Factors influencing aerosol solubility during cloud processes, Atmos. Environ., 35, 3529-3537, 2001.

Desboeufs, K. V., Losno, R., and Colin, J. L.: Figures of merit of pneumatic and ultrasonic sample introduction systems in inductively coupled plasma-multichannel-based emission spectrometry in an ultra-clean environment, Anal. Bioanal. Chem., 375, 567-573, 2003.

Eklund, T. J., McDowell, W. H., and Pringle, C. M.: Seasonal variation of tropical precipitation chemistry: La Selva, Costa Rica, Atmos. Environ., 31, 3903-3910, 1997.

Engelstaedter, S. and Washington, R.: Atmospheric controls on the annual cycle of North African dust, J. Geophys. Res., 112, D03103, doi:10.1029/2006jd007195, 2007.

Formenti, P., Elbert, W., Maenhaut, W., Haywood, J., and Andreae, M. O.: Chemical composition of mineral dust aerosol during the Saharan Dust Experiment (SHADE) airborne campaign in the Cape Verde region, September 2000, J. Geophys. Res., 108, 8576, doi:10.1029/2002jd002648, 2003.

Formenti, P., Rajot, J. L., Desboeufs, K., Caquineau, S., Chevaillier, S., Nava, S., Gaudichet, A., Journet, E., Triquet, S., Alfaro, S., Chiari, M., Haywood, J., Coe, H., and Highwood, E.: Regional variability of the composition of mineral dust from western Africa: Results from the AMMA SOP0/DABEX and DODO field campaigns, J. Geophys. Res., 113, D00C13, doi:10.1029/2008JD009903, 2008.

Galy-Lacaux, C., Laouali, D., Descroix, L., Gobron, N., and Liousse, C.: Long term precipitation chemistry and wet deposition in a remote dry savanna site in Africa (Niger), Atmos. Chem. Phys., 9, 1579-1595, doi:10.5194/acp-9-1579-2009, 2009.

Heartsill-Scalley, T., Scatena, F. N., Estrada, C., McDowell, W. H., and Lugo, A. E.: Disturbance and long-term patterns of rainfall and throughfall nutrient fluxes in a subtropical wet forest in Puerto Rico, J. Hydrol., 333, 472-485, 2007.

Houze, R. A.: Stratiform Precipitation in Regions of Convection: A Meteorological Paradox?, B. Am. Meteorol. Soc., 78, 21792196, 1997.

Janicot, S., Thorncroft, C. D., Ali, A., Asencio, N., Berry, G., Bock, O., Bourles, B., Caniaux, G., Chauvin, F., Deme, A., Kergoat, L., Lafore, J.-P., Lavaysse, C., Lebel, T., Marticorena, B., Mounier, F., Nedelec, P., Redelsperger, J.-L., Ravegnani, F., Reeves, C. E., Roca, R., de Rosnay, P., Schlager, H., Sultan, B., Tomasini, M., Ulanovsky, A., and ACMAD forecasters team: Large-scale overview of the summer monsoon over West Africa during the AMMA field experiment in 2006, Ann. Geophys., 26, 25692595, doi:10.5194/angeo-26-2569-2008, 2008.

Jurado, E., Dachs, J., Duarte, C. M., and Simó, R.: Atmospheric deposition of organic and black carbon to the global oceans, Atmos. 
Environ., 42, 7931-7939, 2008.

Kandler, K. and Schutz, L.: Climatology of the average watersoluble volume fraction of atmospheric aerosol, Atmos. Res., 83, 77-92, 2007.

Karyampudi, V. M., Palm, S. P., Reagen, J. A., Fang, H., Grant, W. B., Hoff, R. M., Moulin, C., Pierce, H. F., Torres, O., Browell, E. V., and Melfi, S. H.: Validation of the Saharan Dust Plume Conceptual Model Using Lidar, Meteosat, and ECMWF Data, B. Am. Meteorol. Soc., 80, 1045-1075, 1999.

Koehler, K. A., Kreidenweis, S. M., DeMott, P. J., Petters, M. D., Prenni, A. J., and Carrico, C. M.: Hygroscopicity and cloud droplet activation of mineral dust aerosol, Geophys. Res. Lett., 36, L08805, doi:10.1029/2009g1037348, 2009.

Lafon, S., Sokolik, I. N., Rajot, J. L., Caquineau, S., and Gaudichet, A.: Characterization of iron oxides in mineral dust aerosols: Implications for light absorption, J. Geophys. Res., 111, D21207, doi:10.1029/2005JD007016, 2006.

Lebel, T., Taupin, J. D., and D'Amato, N.: Rainfall monitoring during HAPEX-Sahel. 1. General rainfall conditions and climatology, J. Hydrol., 188-189, 74-96, 1997.

Lebel, T., Parker, D. J., Flamant, C., Bourlès, B., Marticorena, B., Mougin, E., Peugeot, C., Diedhiou, A., Haywood, J. M., Ngamini, J. B., Polcher, J., Redelsperger, J.-L., and Thorncroft, C. D.: The AMMA field campaigns: multiscale and multidisciplinary observations in the West African region, Q. J. Roy. Meteorol. Soc., 136(S1), 8-33, 2010.

Liu, X., Zhu, J., Van Espen, P., Adams, F., Xiao, R., Dong, S., and Li, Y.: Single particle characterization of spring and summer aerosols in Beijing: Formation of composite sulfate of calcium and potassium, Atmos. Environ., 39, 6909-6918, 2005.

Lothon, M., Saïd, F., Lohou, F., and Campistron, B.: Observation of the Diurnal Cycle in the Low Troposphere of West Africa, Mon. Weather Rev., 136, 3477-3500, 2008.

Maloney, E. D. and Shaman, J.: Intraseasonal Variability of the West African Monsoon and Atlantic ITCZ, J. Climate, 21, 28982918, 2008.

Mari, C. H., Cailley, G., Corre, L., Saunois, M., Attié, J. L., Thouret, V., and Stohl, A.: Tracing biomass burning plumes from the Southern Hemisphere during the AMMA 2006 wet season experiment, Atmos. Chem. Phys., 8, 3951-3961, doi:10.5194/acp-8-3951-2008, 2008.

Mathon, V., Laurent, H., and Lebel, T.: Mesoscale Convective System Rainfall in the Sahel, J. Appl. Meteorol., 41, 1081-1092, 2002.

Matsuki, A., Schwarzenboeck, A., Venzac, H., Laj, P., Crumeyrolle, S., and Gomes, L.: Cloud processing of mineral dust: direct comparison of cloud residual and clear sky particles during AMMA aircraft campaign in summer 2006, Atmos. Chem. Phys., 10, 1057-1069, doi:10.5194/acp-10-1057-2010, 2010.

McConnell, C. L., Highwood, E. J., Coe, H., Formenti, P., Anderson, B., Osborne, S., Nava, S., Desboeufs, K., Chen, G., and Harrison, M. A. J.: Seasonal variations of the physical and optical characteristics of Saharan dust: Results from the Dust Outflow and Deposition to the Ocean (DODO) experiment, J. Geophys. Res., 113, D14S05, doi:10.1029/2007jd009606, 2008.

Mohr, K. I.: Interannual, Monthly, and Regional Variability in the Wet Season Diurnal Cycle of Precipitation in Sub-Saharan Africa, J. Climate, 17, 2441-2453, 2004.

Paris, R., Desboeufs, K. V., Formenti, P., Nava, S., and Chou, C.:
Chemical characterisation of iron in dust and biomass burning aerosols during AMMA-SOP0/DABEX: implication for iron solubility, Atmos. Chem. Phys., 10, 4273-4282, doi:10.5194/acp10-4273-2010, 2010.

Rajot, J. L. and Valentin, C.: Wind Eroded Versus Deposited Mineral Dust: A Mass Budget for a Sahelian Village Land Unit in Niger, J.C. Ascough II and D.C. Flanagan. St. Joseph ed., Soil Erosion Research for the 21st Century, Proc. Int. Symp., American Society of Agricultural Engineers (ASAE), Honolulu, USA, 404-407 pp., 2001.

Rajot, J. L., Formenti, P., Alfaro, S., Desboeufs, K., Chevaillier, S., Chatenet, B., Gaudichet, A., Journet, E., Marticorena, B., Triquet, S., Maman, A., Mouget, N., and Zakou, A.: AMMA dust experiment: An overview of measurements performed during the dry season special observation period (SOP0) at the Banizoumbou (Niger) supersite, J. Geophys. Res.-Atmos., 113, D00C14, doi:10.1029/2008JD009906, 2008.

Redelsperger, J.-L., Thorncroft, C. D., Diedhiou, A., Lebel, T., Parker, D. J., and Polcher, J.: African Monsoon Multidisciplinary Analysis: An International Research Project and Field Campaign, B. Am. Meteorol. Soc., 87, 1739-1746, 2006.

Schepanski, K., Tegen, I., Todd, M. C., Heinold, B., Bänisch, G., Laurent, B., and Macke, A.: Meteorological processes forcing Saharan dust emission inferred from MSG-SEVIRI observations of subdaily dust source activation and numerical models, J. Geophys. Res., 114, D10201, doi:10.1029/2008jd010325, 2009.

Seco, R., Peñuelas, J., and Filella, I.: Short-chain oxygenated VOCs: Emission and uptake by plants and atmospheric sources, sinks, and concentrations, Atmos. Environ., 41, 2477-2499, 2007.

Sow, M., Alfaro, S. C., Rajot, J. L., and Marticorena, B.: Size resolved dust emission fluxes measured in Niger during 3 dust storms of the AMMA experiment, Atmos. Chem. Phys., 9, 38813891, doi:10.5194/acp-9-3881-2009, 2009.

Spaan, W. P. and van den Abeele, G. D.: Wind born particle measurements with acoustic sensors, Soil Technol., 4, 51-63, 1991.

Sterk, G.: Causes, consequences and control of wind erosion in Sahelian Africa: a review, Land Degradation \& Development, 14, 95-108, 2003.

Stewart, D. J., Taylor, C. M., Reeves, C. E., and McQuaid, J. B.: Biogenic nitrogen oxide emissions from soils: impact on $\mathrm{NO}_{\mathrm{x}}$ and ozone over west Africa during AMMA (African Monsoon Multidisciplinary Analysis): observational study, Atmos. Chem. Phys., 8, 2285-2297, doi:10.5194/acp-8-2285-2008, 2008.

Sullivan, R. C., Guazzotti, S. A., Sodeman, D. A., and Prather, K. A.: Direct observations of the atmospheric processing of Asian mineral dust, Atmos. Chem. Phys., 7, 1213-1236, doi:10.5194/acp-7-1213-2007, 2007.

Tegen, I. and Fung, I.: Contribution to the atmospheric mineral aerosol load from land surface modification, J. Geophys. Res., 100, 18707-18726, 1995.

Washington, R., Todd, M. C., Lizcano, G., Tegen, I., Flamant, C., Koren, I., Ginoux, P., Engelstaedter, S., Bristow, C. S., Zender, C. S., Goudie, A. S., Warren, A., and Prospero, J. M.: Links between topography, wind, deflation, lakes and dust: The case of the Bodélé Depression, Chad, Geophys. Res. Lett., 33, L09401, doi:10.1029/2006g1025827, 2006. 